\title{
Agronomic Efficiency of Phosphorus Fertilizers With Associate Technology in Soy Crop in Cerrado Soil
}

\author{
Victor Gustavo Soares Ribeiro ${ }^{1}$, Carlos Henrique Eiterer de Souza ${ }^{2}$, Murilo Mendes Machado ${ }^{2}$, \\ Lara Lúcia Gonçalves ${ }^{2}$, Miguel Martins Neto ${ }^{3}$, Edilson Souza Santos ${ }^{2} \&$ Henrique Teixeira Santos ${ }^{2}$ \\ ${ }^{1}$ Federal University of Viçosa, Viçosa, MG, Brazil \\ ${ }^{2}$ University Center of Patos de Minas, Patos de Minas, MG, Brazil \\ ${ }^{3}$ Federal University of Uberlândia, Uberlândia, MG, Brazil \\ Correspondence: Victor Gustavo Soares Ribeiro, Federal University of Viçosa (UFV), Viçosa, MG, Brazil. E-mail: \\ victorgustavo.sr@gmail.com
}

Received: May 31, 2021

doi:10.5539/jas.v13n10p61
Accepted: August 15, $2021 \quad$ Online Published: September 15, 2021

URL: https://doi.org/10.5539/jas.v13n10p61

\begin{abstract}
For commercial soybean production, the presence of phosphorus in the soil is essential, not only to increase productivity but also because it affects basic functions in plant metabolism. Phosphate fertilizers have low efficiency in Cerrado soils. For this reason, the use of technologies associated with phosphate fertilizers is important to increase their efficiency in the soil. The experiment was conducted at Fazenda Rio Brilhante in Coromandel, MG. The experiment was laid out in a randomized block design in a $4 \times 4+1$ factorial arrangement. Treatments consisted of four phosphate fertilizer sources $\left(\mathrm{MAP}_{\mathrm{CONVENCIONAL}}, \mathrm{MAP}_{\text {pol 1 }}, \mathrm{MAP}_{\text {pol } 2 \text {, }}\right.$ and $\mathrm{FOM}$ ), four $\mathrm{P}_{2} \mathrm{O}_{5}$ doses $\left(40,80,120\right.$, and $160 \mathrm{~kg} \mathrm{ha}^{-1}$ ), and the control treatment (no phosphorus application). The soybean cultivar RK8115 IPRO with a plant population of 340 thousand plants per hectare was used. The experimental plots consisted of five planting lines with a spacing of 0.5 meters and a length of 7 meters. In the experiment, phosphorus leaf, morphological evaluation of plant height, stem diameter, number of stems, and pods were measured. For plant biomass, the dry matter of leaves, stems, and pods were determined. For yield

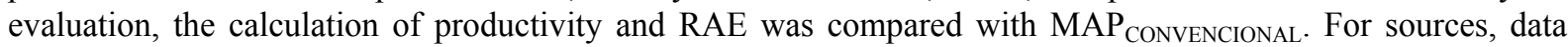
were subjected to analysis of variance, and means were separated by Tukey's rate test $(\mathrm{p}<0.05)$. For $\mathrm{P}_{2} \mathrm{O}_{5}$ doses, regression model fitting was performed using the ExpDes.pt package of $\mathrm{R}$ Studio software. Morphological assessments responded linearly to P doses, except for DPM. Leaves and pods P content and yield were affected by $\mathrm{P}$ dosage and $\mathrm{P}$ sources, with a quadratic response to $\mathrm{P}$ dosage. Maximum yield efficiency was achieved at $\mathrm{P}_{2} \mathrm{O}_{5}$ doses of $122.73 ; 145.07 ; 112.03$; and $94.71 \mathrm{~kg} \mathrm{ha}^{-1}$, with yields of $3818.30 ; 4064.67 ; 4089.03$; and 3952.63 $\mathrm{kg} \mathrm{ha}^{-1}$ for MAP $\mathrm{MONVENCIONAL}, \mathrm{MAP}_{\text {pol 2 }}, \mathrm{MAP}_{\text {pol }} 1$, and FOM, respectively. However, $\mathrm{MAP}_{\text {pol } 1}$ and FOM provided a dose reduction of 26 and 15 compared to the maximum yield of $\mathrm{MAP}_{\text {CONVENCIONAL }}$, respectively.
\end{abstract}

Keywords: organomineral, polymers, yield

\section{Introduction}

In a bulletin published in February 2020, soybean production in Brazil will reach a historical record of 123.25 million tons, with average productivity of $3,349 \mathrm{~kg} \mathrm{ha}^{-1}$, representing increases of 7.1 and $4.4 \%$, respectively, over the previous harvest, both in production and productivity. The area planted also increased by $2.6 \%$ in this crop compared to the previous crop, reaching a total of 36.8 million hectares (CONAB, 2020). For the commercial cultivation of soybeans, the presence of phosphorus in the soil is essential, since it performs basic functions in the metabolism of plants, which can lead to a significant increase in productivity (Araujo, 2005).

In Cerrado soils, where highly weathered soils predominate, phosphorus $(\mathrm{P})$ is considered one of the limiting nutrients for biomass production (Novais \& Smyth, 1999). This is because P performs functions such as plant development, component of nucleic acids, proteins, ATP, genetic material, energy storage and transfer, photosynthesis, regulation of enzymatic processes, root development and seed formation (Malavolta, 2006; Zambolim, 2001; Dechen \& Nachtigall, 2007).

Oxisols are the soil class that represents about $45.7 \%$ of Cerrado soils. They are described as highly weathered, deep, with clay contents ranging from 15 to $80 \%$ and low availability of nutrients, especially P. These soils 
contain predominantly clay minerals of the 1:1 type, as well as iron oxides (hematite and goethite) and aluminum (gibsite). These factors increase and control the availability and adsorption of $\mathrm{P}$ in the soil (Stauffer, 2016), which contributes to low concentration of the nutrient in the soil (Fink et al., 2014) and negatively affects the diffusive P flux (FDP) in the soil (Raghothama \& Karthikeyan, 2005). Additionally, Hopkins (2015) says that the recovery capacity of phosphorus applied by fertilizers in tropical soils ranges from 0.1 to $30 \%$, depending on the $\mathrm{pH}$ and type of clay in the soil.

Hence, alternatives to increase the efficiency of phosphate fertilization in Cerrado soils include the use of coating polymers or related technologies and the use of organomineral fertilizers. The accompanying technologies may be gradual or controlled release (Machado \& Souza, 2012), the use of polymers with high density of negative charges that bind interfering divalent or trivalent cations (Dunn \& Stevens, 2008), or the use of organic acids (Sas et al., 2001), which are components of organophosphate fertilizers. These technologies aim to mitigate the impairment of soil $\mathrm{P}$ availability by cations and clays in order to increase the available $\mathrm{P}$ in the soil solution for subsequent uptake by plants.

Therefore, the objective of the present work is to evaluate the response of soybean cultivation and the agronomic efficiency of phosphate fertilizers with appropriate technology in the Cerrado, crop 2019/2020, in the Alto Paranaíba region, $\mathrm{MG}$.

\section{Methodology}

The experiment was conducted at Fazenda Rio Brilhante in the municipality of Coromandel, MG, at geographic coordinates $18^{\circ} 35^{\prime} 48.5^{\prime \prime} \mathrm{S} 46^{\circ} 53^{\prime} 55.6^{\prime \prime} \mathrm{W}$. The climate of the region is classified as Aw with two well-defined seasons, rainy summers and dry winters (Köppen, 1931).

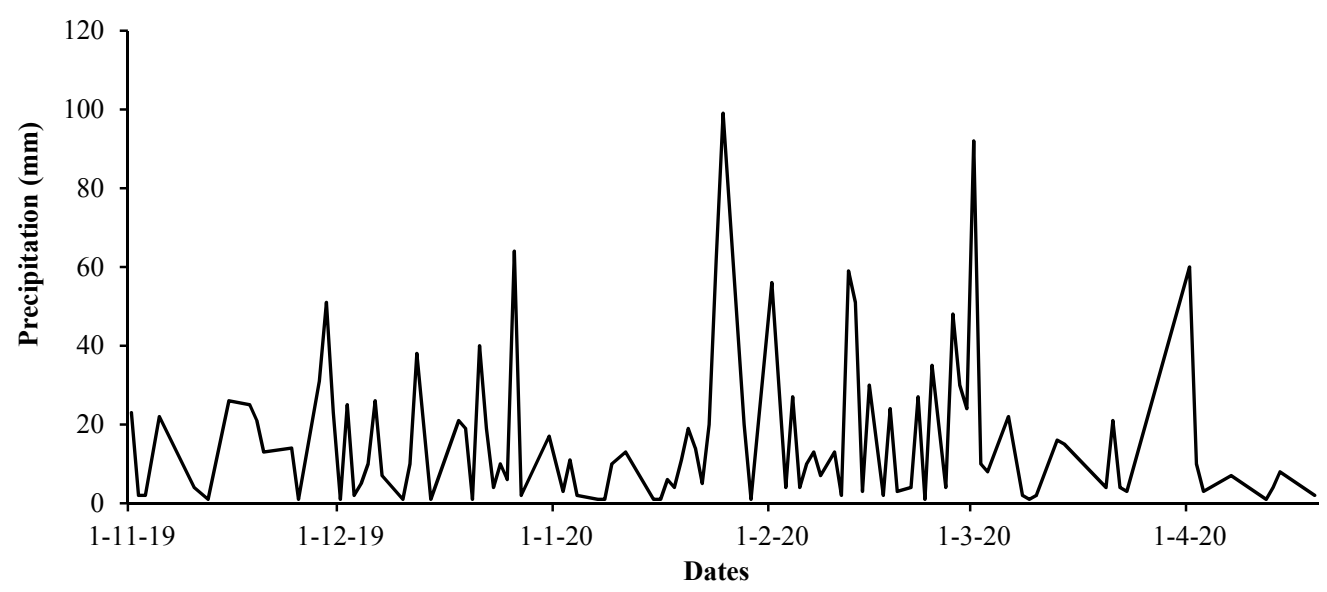

Figure 1. Rainfall data during the conduct of the experiment. Coromandel, MG. 2020

The experiment was laid out in a randomized block design (DBC) and in a $4 \times 4+1$ factorial scheme with four replications. Four phosphate fertilizer sources $\left(\mathrm{MAP}_{\mathrm{CONVENCIONAL}}, \mathrm{MAP}_{\mathrm{pol} 1}, \mathrm{MAP}_{\mathrm{pol} 2}\right.$ and organomineral source (FOM-06-26-00)), four $\mathrm{P}_{2} \mathrm{O}_{5}$ doses $\left(40,80,120\right.$ and $160 \mathrm{~kg} \mathrm{ha}^{-1}$ ) and one control treatment (no phosphorus application) were used. Soybean cultivar RK8115 IPRO with indeterminate cycle, maturity group 8.1 and plant population of 340 thousand plants ha ${ }^{-1}$ was used. The experimental plots consisted of five plots, $0.5 \mathrm{~m}$ apart and $7 \mathrm{~m}$ long, with a total area of $17.5 \mathrm{~m}^{2}$.

For the chemical characterization of the soil, a soil sample was collected from the experimental area and then analyzed according to the methods proposed by EMBRAPA (2017). 
Table 1. Chemical characterization of the experimental area before the installation of the experiment. Patos de Minas, 2020

\begin{tabular}{|c|c|c|c|c|c|c|c|c|c|c|c|c|c|}
\hline $\mathrm{pH}$ & M.O. & P-rem & P-meh & $\mathrm{K}^{+}$ & $\mathrm{Ca}^{2+}$ & $\mathrm{Mg}^{2+}$ & $\mathrm{Al}^{3+}$ & $\mathrm{H}+\mathrm{Al}$ & SB & $\mathrm{t}$ & $\mathrm{T}$ & V & $\mathrm{m}$ \\
\hline water & dag $\mathrm{Kg}^{-1}$ & $\mathrm{mg} \mathrm{L}^{-1}$ & \multicolumn{2}{|c|}{---- $\mathrm{mg} \mathrm{dm}^{-3}$} & \multicolumn{7}{|c|}{----'--- $\mathrm{cmol}_{\mathrm{c}} \mathrm{dm}^{-3}$} & \multicolumn{2}{|c|}{------ \% ------ } \\
\hline 6.50 & 4.39 & 11.96 & 1.87 & 126.00 & 2.70 & 1.50 & 0.01 & 4.20 & 4.52 & 4.53 & 8.72 & 51.85 & 0.22 \\
\hline
\end{tabular}

Note. OBS.: $\mathrm{pH}$ in water; $\mathrm{Ca}^{2+}, \mathrm{Mg}^{2+}$ and $\mathrm{Al}^{3+}$ extractor $\mathrm{KCl} 1 \mathrm{~mol} \mathrm{~L}^{-1}$; P-rem solution $\mathrm{CaCl} 0.01 \mathrm{~mol} \mathrm{~L}^{-1}$ containing $60 \mathrm{mg} \mathrm{L}^{-1}$ of $\mathrm{P}$; P-meh and $\mathrm{K}^{+}$mehlich ${ }^{1}$ extractor; $\mathrm{H}+\mathrm{Al}$ extractor Calcium acetate $1 \mathrm{~mol} \mathrm{~L}^{-1}$ at $\mathrm{pH} 7.0$; M.O. determined by the Walkley-Black method.

To apply the treatments, the planting lines were first marked with a seeder, which served as a reference for opening the furrows. The furrows were opened manually and then the treatments were applied. The furrows were covered, and the sowing was done mechanically with the same machines used for marking the lines. Leaf phosphorus content (P-leaf) was measured and morphological values such as plant height, stem diameter, number of stems and pods, plant biomass (leaves, stems, and pods dry matter- LDM, SDM, and PDM respectively) were determined. In addition, an analysis of productivity and relative agronomic efficiency (RAE) of the treatments was carried out in comparison with MAP ${ }_{\text {CONVENCIONAL }}$.

The P-leaf analysis was conducted when the plants were at the R2 stage (full flowering). Ten clovers per plot were collected for this assessment, with the third fully developed clover leaf counted from the apex of the plant. These were placed in paper bags, properly labeled, and sent to the Laboratory and Central of Soil Fertility Analysis (CeFert), where they were stored in a convection oven at $65^{\circ} \mathrm{C}$ until they reached a constant mass. Then the samples were ground in a Willey mill, weighed $0.5 \mathrm{~g}$, and placed in an electric muffle furnace at $500{ }^{\circ} \mathrm{C}$ until complete digestion of the organic part of the plant tissue. Then, the extraction method $\left(\mathrm{HNO}_{3} 1 \mathrm{~mol}\right.$ $\mathrm{L}^{-1}$ ) and quantification of $\mathrm{P}$ content in leaf tissue were carried out according to the vanadate yellow method proposed by EMBRAPA (2009).

Morphological assessments were made when plants were at phenological stage R5, which corresponds to the phenological stage of filling initiation. Two plants per plot were removed and taken to CeFert to evaluate the morphological parameters. Plant height was measured from the crown to the top of the plant using a tape measure labeled in centimeters. The diameter was measured in millimeters between the first and second nodes at the plant neck using a digital caliper. The number of stems and pods was determined by manually counting each plant structure.

LDM, SDM, and PDM assessments were made on the plants used for the morphological assessments. For this purpose, plants were dissected into leaves, stems, and pods, placed in paper bags, and placed in a convection oven at $65^{\circ} \mathrm{C}$ until they reached a constant mass. The samples were then weighed on an analytical balance. For yield evaluation, only the usable area of each plot was recorded, i.e., excluding the end lines and one meter at the beginning and end of each plot, corresponding to a usable area of $7.5 \mathrm{~m}^{2}$. After collection, the pods were threshed manually and weighed on an analytical balance and the result was extrapolated to kilo ha ${ }^{-1}$.

The relative agronomic efficiency index was calculated according to Prochnow et al. (2003):

$$
\operatorname{RAE}(\%)=\frac{\mathrm{Y}_{\text {Source } \mathrm{i}}-\mathrm{Y}_{\text {Untreated }}}{\mathrm{Y}_{\text {Standatsource }}-\mathrm{Y}_{\text {Untreated }}} \times 100
$$

where, RAE: Relative agronomic efficiency (\%); $\mathrm{Y}_{\text {Source } i}$ : grain productivity with phosphate fertilizer; $\mathrm{Y}_{\text {Untreated }}$ : grain yield without phosphate fertilizer; $\mathrm{Y}_{\text {Standat-source }}$ : productivity obtained with the fertilizer MAP $\mathrm{P}_{\text {CONVENCIONAL }}$.

Data were subjected to the residual normality test (Shapiro-Wilk) followed by analysis of variance. Means were compared using Tukey's test $(\mathrm{p}<0.05)$ for sources, and the regression model was fitted for $\mathrm{P}_{2} \mathrm{O}_{5}$ doses using the ExpDes.pt package (Ferreira et al., 2018) in R Studio software (Rstudio Team, 2016).

\section{Results and Discussion}

The ratings of LDM, SDM, stem diameter, and plant height (Figure 2) were affected only by the $\mathrm{P}_{2} \mathrm{O}_{5}$ doses, and these responded linearly up to a $\mathrm{P}_{2} \mathrm{O}_{5}$ dose of $160 \mathrm{~kg} \mathrm{ha}^{-1}$. The ratings of PDM, P-leaf, number of pods, and productivity were affected by the interaction between the source and dose factors. 

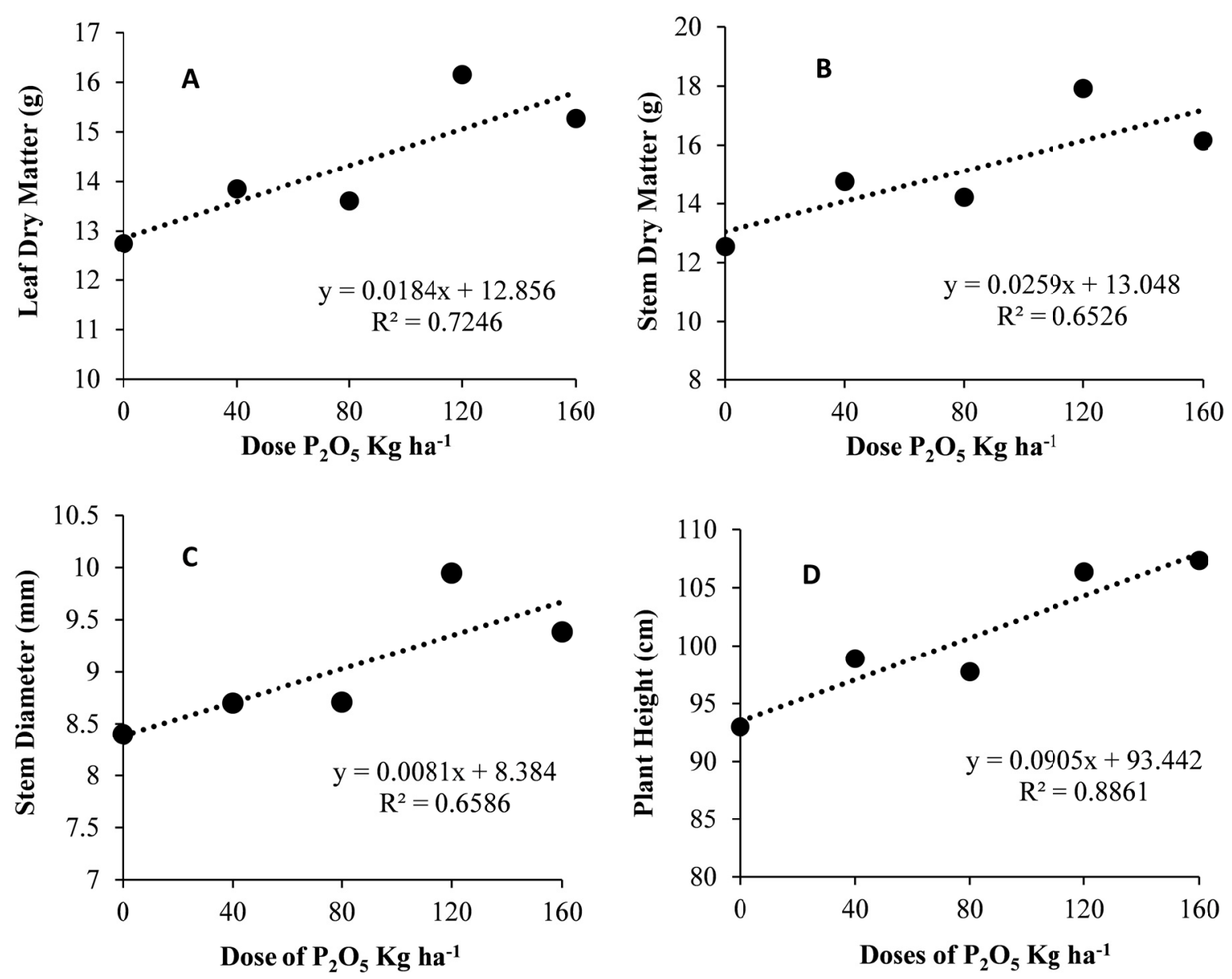

Figure 2. Leaf dry mass (A), stem dry mass (B), stem diameter (C) and height of soybean plants (D) in response to phosphorus doses. Coromandel, 2020

Figure 2 shows that LDM, SDM, diameter and height of plants increased linearly with phosphorus dosage and reached a maximum of $16.16 \mathrm{~g}_{\text {plant }}{ }^{-1}, 17.92 \mathrm{~g} \mathrm{plant}^{-1}, 9.95 \mathrm{~mm}$ and $107.36 \mathrm{~cm}$, respectively. These results confirm those of Corrêa et al. (2004), who observed an increasing trend in the dry matter of the aerial parts, plant height and stem diameter of soybean under phosphorus dosing, with the highest values obtained at a dose of 150 $\mathrm{kg} \mathrm{ha}^{-1} \mathrm{P}_{2} \mathrm{O}_{5}$. These results can be explained by the fact that soil phosphorus adsorption capacity decreases with increasing soil phosphorus concentration (Whalen \& Chang, 2002).

The evaluation of growth by quantifying the dry matter of plants is an important parameter for assessing their behavior, since several physiological processes intervene in their development (Benicasa, 2003). A plant with higher dry matter allows a greater transfer of photoassimilates from the vegetative organs to the reproductive organs. Thus, plant dry matter becomes a crucial factor for plant productivity (Teodoro et al., 2015).

For the variable PDM (Table 2), the sources differed only at the doses of 40 and $160 \mathrm{~kg} \mathrm{ha}^{-1} \mathrm{P}_{2} \mathrm{O}_{5}$. At the dose of $40 \mathrm{~kg} \mathrm{ha}^{-1} \mathrm{P}_{2} \mathrm{O}_{5}, \mathrm{MAP}_{\text {CONVENTIONAL }}, \mathrm{MAP}_{\text {pol } 2}$ and FOM sources obtained the best average values with values of $6.46,6.95$ and $7.49 \mathrm{~g}$ per plant $^{-1}$, respectively. At the dose of $160 \mathrm{~kg} \mathrm{ha}^{-1} \mathrm{P}_{2} \mathrm{O}_{5}$, the highest value was obtained by $\mathrm{MAP}_{\mathrm{pol} 1}$ application and the lowest value by FOM application. The other sources, including $\mathrm{MAP}_{\mathrm{pol} 11}$ and FOM, did not differ from each other. 
Table 2. Average pods dry matter of soybean exposed to the different phosphate fertilizer doses and sources. Coromandel, 2020

\begin{tabular}{lllllll}
\hline \multirow{2}{*}{ Sources } & \multicolumn{5}{c}{ Doses of $\mathrm{P}_{2} \mathrm{O}_{5}$ in $\mathrm{kg} \mathrm{ha}^{-1}$} & Average \\
\cline { 2 - 6 } & 0 & 40 & 80 & 120 & 160 & 6.72 \\
\hline MAP & $6.42 \mathrm{a}$ & $6.46 \mathrm{ab}$ & $6.03 \mathrm{a}$ & $7.57 \mathrm{a}$ & $7.11 \mathrm{ab}$ & 6.43 \\
FOM & $6.42 \mathrm{a}$ & $7.49 \mathrm{a}$ & $6.22 \mathrm{a}$ & $6.46 \mathrm{a}$ & $5.58 \mathrm{~b}$ & 6.63 \\
$\mathrm{MAP}_{\text {pol 1 }}$ & $6.42 \mathrm{a}$ & $5.55 \mathrm{~b}$ & $5.6 \mathrm{a}$ & $7.96 \mathrm{a}$ & $7.60 \mathrm{a}$ & 6.66 \\
MAP $_{\text {pol 2 }}$ & $6.42 \mathrm{a}$ & $6.95 \mathrm{ab}$ & $5.97 \mathrm{a}$ & $7.57 \mathrm{a}$ & $6.38 \mathrm{ab}$ & 6.66 \\
\hline Average & 6.42 & 6.61 & 5.96 & 7.39 & 6.67 & \\
CV (\%): 13.61 & & & & & & \\
DMS: 1.69 & & & & & \\
\hline
\end{tabular}

Note. ${ }^{1}$ Mean scores with same letters in column do not differ by Tukey's test at 0.05 significance.

In the significant interaction between sources and doses for the P-leaf variable (Table 3 and Figure 3), it is noted that when sources were partitioned within doses, there was a significant difference between sources only for the doses of 40 and $160 \mathrm{~kg} \mathrm{ha}^{-1} \mathrm{P}_{2} \mathrm{O}_{5}$, and when doses were partitioned within sources, there was a significant quadratic fit for all sources. Accordingly, the highest P-leaf contents were obtained by the application of MAP $\mathrm{CONVENCIONAL}_{\text {, }}$ FOM, MAP ${ }_{\text {pol } 2}$ and $\mathrm{MAP}_{\text {pol } 1}$ at doses of $100.75 ; 166.00 ; 106.25$ and $181.25 \mathrm{~kg} \mathrm{ha}^{-1} \mathrm{P}_{2} \mathrm{O}_{5}$, reaching contents of 3.59 ; $4.50 ; 4.07$ and $4.38 \mathrm{~g} \mathrm{~kg}^{-1}$, respectively.

Table 3. Average values of P-leaf content of soybean fertilized with phosphate fertilizers at different rates and from different sources. Coromandel, 2020

\begin{tabular}{|c|c|c|c|c|c|c|}
\hline \multirow{2}{*}{ Sources } & \multicolumn{5}{|c|}{ Doses of $\mathrm{P}_{2} \mathrm{O}_{5} \mathrm{~kg} \mathrm{ha}^{-1}$} & \multirow{2}{*}{ Average } \\
\hline & 0 & 40 & 80 & 120 & 160 & \\
\hline MAP $_{\text {CONVENCIONAL }}$ & $1.49 \mathrm{a}$ & $2.99 b$ & $3.59 \mathrm{a}$ & $3.48 \mathrm{a}$ & $3.2 \mathrm{~b}$ & 2.95 \\
\hline FOM & $1.49 \mathrm{a}$ & $3.4 \mathrm{ab}$ & $3.21 \mathrm{a}$ & $3.42 \mathrm{a}$ & $3.54 b$ & 3.02 \\
\hline $\mathrm{MAP}_{\mathrm{pol} 1}$ & $1.49 \mathrm{a}$ & $3.35 \mathrm{ab}$ & $3.47 \mathrm{a}$ & $3.65 \mathrm{a}$ & $4.59 \mathrm{a}$ & 3.31 \\
\hline $\mathrm{MAP}_{\mathrm{pol} 2}$ & $1.49 \mathrm{a}$ & $3.88 \mathrm{a}$ & $3.58 \mathrm{a}$ & $3.37 \mathrm{a}$ & $3.26 b$ & 3.11 \\
\hline Average & 1.49 & 3.35 & 3.46 & 3.48 & 3.64 & \\
\hline \multicolumn{7}{|l|}{$\mathrm{CV}(\%): 13.37$} \\
\hline DMS: 0.775 & & & & & & \\
\hline
\end{tabular}

Note. ${ }^{1}$ Mean scores with same letters in column do not differ by Tukey's test at 0.05 significance. 


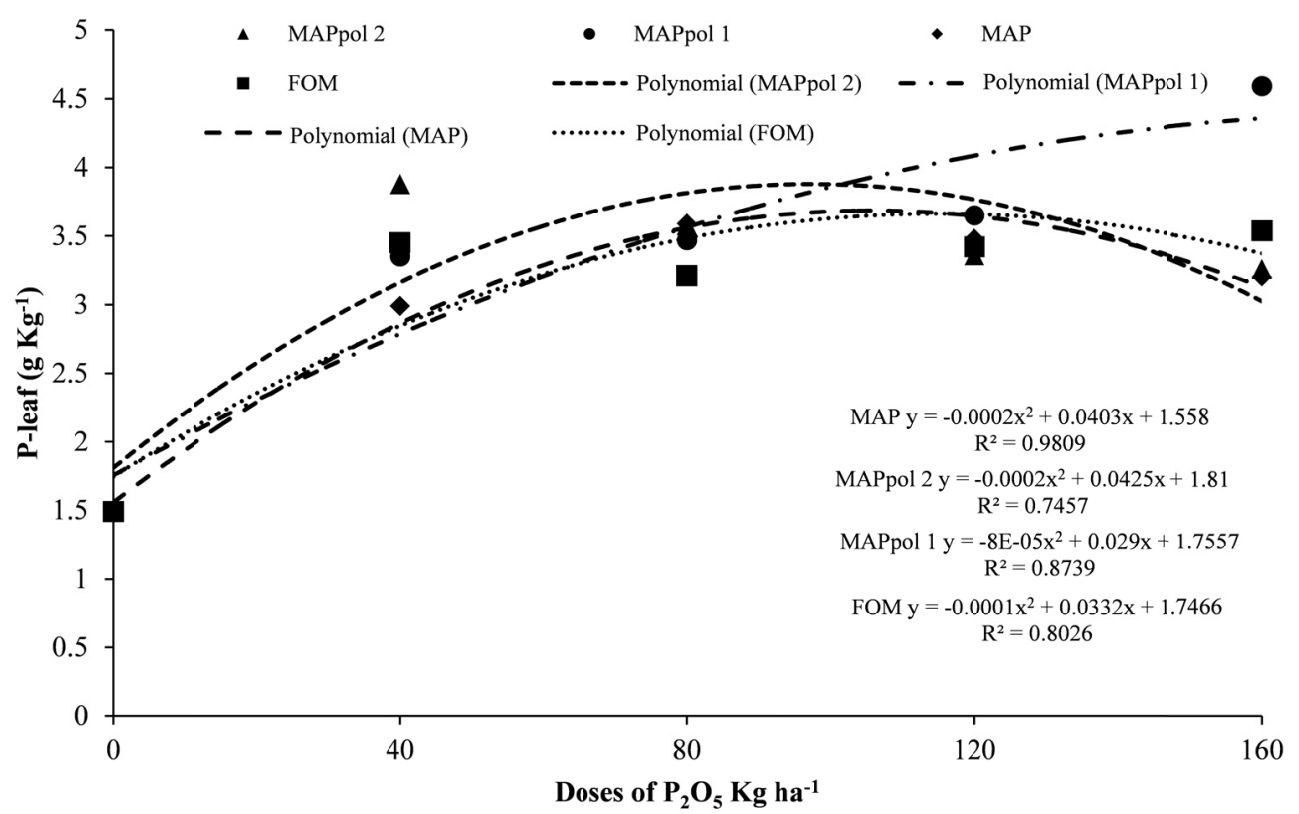

Figure 3. Foliar P of soybean crop submitted to doses and sources of phosphate fertilizers. Coromandel, 2020

For pod evaluation by plants (Table 4), there was a significant interaction between sources and doses, but there was a partitioning only for sources within doses. For productivity (Table 5 and Figure 4), there was also a significant interaction between sources and doses for both sources within doses and doses within source, with quadratic regression models fitted for all sources. It is worth mentioning that for both leaf $P$ values (Table 3), number of pods per plant (Table 4) and productivity (Table 5), the best average values were obtained at a dose of $120 \mathrm{~kg} \mathrm{ha}^{-1} \mathrm{P}_{2} \mathrm{O}_{5}$ regardless of sources. The available phosphorus (P-meh) of the soil before the establishment of the experiment was classified as "very low", and the dose of $120 \mathrm{~kg} \mathrm{ha}^{-1} \mathrm{P}_{2} \mathrm{O}_{5}$, at which the highest average values of the above variables were found, is in accordance with the recommendations for soils with this CFSEMG classification (1999).

Figure 4 shows the points of maximum efficiency at doses of $122.7 ; 145.07 ; 112.03$ and $94.71 \mathrm{~kg} \mathrm{ha}^{-1} \mathrm{P}_{2} \mathrm{O}_{5}$, with yields of 3818.30; 4064.67; 4089.03 and $3952.63 \mathrm{~kg} \mathrm{ha}^{-1}$ for MAP $\mathrm{CONVENCIONAL}_{\text {, MAP }}$ pol 2, MAP $\mathrm{pol}_{1}$ and FOM sources, respectively. It can also be seen from Figure 4 that the results are in agreement with the "Law of Diminishing Returns" which states that after a certain dose of phosphorus, the plant does not respond productively to the same extent. It can also be observed that FOM was the most productive when the lowest dose of $\mathrm{P}_{2} \mathrm{O}_{5}$ was used, followed by $\mathrm{MAP}_{\mathrm{pol}}$, which allowed a reduction in doses of 26 and $15 \%$, respectively, compared to the higher productivity of the MAP $\mathrm{CONVENCIONAL}_{\text {source. }}$

This result can be explained by the composition of the FOM and MAP $\mathrm{pol}_{1}$ sources. FOM contains organic acids that form stable organometallic complexes with $\mathrm{Fe}$ and $\mathrm{Al}$ on the surface of oxidic clays (Sposito, 1989), and the more stable these complexes are, the more phosphorus adsorption by clays is reduced (Bar-Yosef, 1996). In addition, Stevenson (1986) says that organic acids (humic and fulvic acids) form a kind of "protective barrier" around $\mathrm{Fe}$ and $\mathrm{Al}$ oxides, making phosphorus adsorption more difficult. The $\mathrm{MAP}_{\mathrm{pol} 1}$ source contains itaconic maleic acid (negatively charged) in its composition, which forms a kind of "protective barrier" around the fertilizer granules, sequesters sequestering $\mathrm{Fe}$ and $\mathrm{Al}$ from the soil solution and additionally binding oxidic clays, reducing phosphorus adsorption and increasing its availability (Hopkins et al., 2017).

As mentioned in the paper, other authors also found positive results and fits of a significant quadratic regression model for soybean yields under phosphorus dosages in experiments conducted at Brazilian Cerrado (Neto et al., 2010; Santos et al., 2015). In addition, Souza et al. (2020) obtained similar results to the present work when using dosages and phosphate sources with coating technologies in corn and field bean crops, demonstrating greater efficiency of polymerized fertilizers and dose reduction when using this type of source. 
Table 4. Average number of pods per plant in soybeans fertilized with different phosphate fertilizer doses and sources. Coromandel, 2020

\begin{tabular}{|c|c|c|c|c|c|c|}
\hline \multirow{2}{*}{ Sources } & \multicolumn{5}{|c|}{ Doses of $\mathrm{P}_{2} \mathrm{O}_{5} \mathrm{~kg} \mathrm{ha}^{-1}$} & \multirow{2}{*}{ Average } \\
\hline & 0 & 40 & 80 & 120 & 160 & \\
\hline MAP $_{\text {CONVENCIONAL }}$ & $47.5 \mathrm{a}$ & $47.38 \mathrm{ab}$ & $45.63 \mathrm{a}$ & $59.88 \mathrm{a}$ & $54.88 \mathrm{ab}$ & 51.05 \\
\hline FOM & $47.5 \mathrm{a}$ & $59.25 \mathrm{a}$ & $45 \mathrm{a}$ & $46 \mathrm{a}$ & $38 \mathrm{~b}$ & 47.15 \\
\hline $\mathrm{MAP}_{\mathrm{pol} 1}$ & $47.5 \mathrm{a}$ & $40.13 b$ & $39.88 \mathrm{a}$ & $63.3 \mathrm{a}$ & $59.25 \mathrm{a}$ & 50.01 \\
\hline $\mathrm{MAP}_{\mathrm{pol} 2}$ & $47.5 \mathrm{a}$ & $50.38 \mathrm{ab}$ & $41.88 \mathrm{a}$ & $62 \mathrm{a}$ & $42.88 \mathrm{ab}$ & 48.93 \\
\hline Average & 47.50 & 49.29 & 43.10 & 57.80 & 48.75 & \\
\hline \multicolumn{7}{|l|}{ CV (\%): 20.70} \\
\hline DMS: 19.097 & & & & & & \\
\hline
\end{tabular}

${ }^{1}$ Mean scores with same letters in column do not differ by Tukey's test at 0.05 significance.

Table 5. Average soybean crop productivity as a function of phosphate fertilizer dosage and source. Coromandel, 2020

\begin{tabular}{|c|c|c|c|c|c|c|}
\hline \multirow{2}{*}{ Sources } & \multicolumn{5}{|c|}{ Doses of $\mathrm{P}_{2} \mathrm{O}_{5} \mathrm{~kg} \mathrm{ha}^{-1}$} & \multirow{2}{*}{ Average } \\
\hline & 0 & 40 & 80 & 120 & 160 & \\
\hline MAP & $2647.55 a$ & $3517.85 b$ & $3628.25 \mathrm{a}$ & $3704.57 \mathrm{ab}$ & $3785.8 \mathrm{ab}$ & 3456.8 \\
\hline FOM & $2647.55 a$ & $3947.56 a$ & $3838.45 \mathrm{a}$ & $3615.22 b$ & $3558.10 \mathrm{~b}$ & 3521.38 \\
\hline $\mathrm{MAP}_{\mathrm{pol} 1}$ & $2647.55 \mathrm{a}$ & $3620.97 \mathrm{ab}$ & $3968.92 \mathrm{a}$ & $3984.82 \mathrm{ab}$ & $3884.67 \mathrm{ab}$ & 3621.39 \\
\hline $\mathrm{MAP}_{\mathrm{pol} 2}$ & $2647.55 a$ & $3245.30 \mathrm{~b}$ & $3783.80 \mathrm{a}$ & $4068.51 \mathrm{a}$ & $4023.49 \mathrm{a}$ & 3553.73 \\
\hline Average & 2647.55 & 3582.92 & 3804.86 & 3843.28 & 3813.015 & \\
\hline \multicolumn{7}{|l|}{$\mathrm{CV}(\%): 5.94$} \\
\hline DMS: 393.524 & & & & & & \\
\hline
\end{tabular}

${ }^{1}$ Mean scores with same letters in column do not differ by Tukey's test at 0.05 significance.

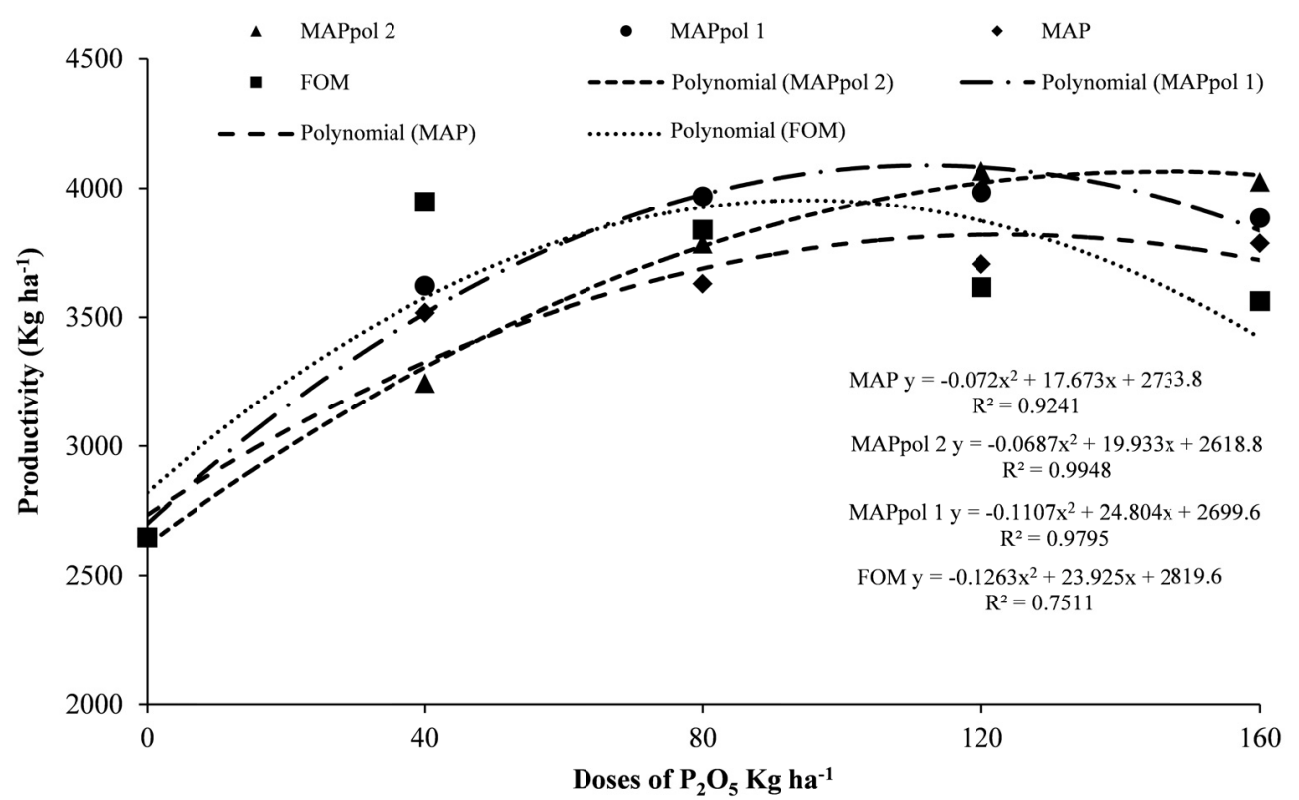

Figure 4. Soybean crop productivity as a function of phosphate fertilizer rate and source. Coromandel, 2020

Table 6 shows the relative agronomic efficiency of phosphorus application in soybean production. It can be seen that on the average of both sources and dosages, there is an increase in RAE compared to MAP CONVENTIONAL $_{\text {. The }}$ higher yields in polymerized fertilizers were a result of higher RAE. Similar results were found by Souza et al. (2020) and Zanão et al. (2020) who reported higher RAE in fertilizers with associated technologies. 
Table 6. Relative agronomic efficiency of soybean cultivation as a function of phosphorus dosage

\begin{tabular}{llllll}
\hline \multirow{2}{*}{ Sources } & \multicolumn{5}{c}{ Relative Agronomic Efficiency (\%) } \\
\cline { 2 - 5 } & 40 & 80 & 120 & 160 & Average \\
\hline FOM & 151.49 & 125.98 & 97.24 & 88.15 & 115.71 \\
MAP $_{\text {pol 1 }}$ & 111.95 & 137.98 & 142.65 & 120.74 & 128.33 \\
MAP $_{\text {pol 2 }}$ & 71.51 & 118.82 & 150.39 & 137.55 & 119.57 \\
\hline Average & 111.65 & 127.59 & 130.09 & 115.48 & \\
\hline
\end{tabular}

\section{Conclusion}

The use of phosphate sources with associated technologies resulted in an increase in the relative agronomic

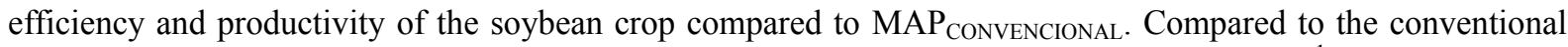
MAP, the application of FOM showed an increase in agronomic efficiency at 40 and $80 \mathrm{~kg} \mathrm{ha}^{-1} \mathrm{P}_{2} \mathrm{O}_{5}$, while with $\mathrm{MAP}_{\mathrm{pol} 11}$ and $\mathrm{MAP}_{\mathrm{pol} 2}$ additives, the highest values of agronomic efficiency were obtained at doses above $80 \mathrm{~kg}$ $\mathrm{ha}^{-1} \mathrm{P}_{2} \mathrm{O}_{5}$. At a dose of $120 \mathrm{~kg} \mathrm{ha}^{-1} \mathrm{P}_{2} \mathrm{O}_{5}$, the use of $\mathrm{MAP}_{\mathrm{pol} 11}$ and $\mathrm{MAP}_{\mathrm{pol} 2}$ resulted in an increase in agronomic efficiency of 50 to $40 \%$ compared to the conventional MAP, indicating the potential of the additives to increase productivity.

\section{Acknowledgements}

We are happy to contribute data for the efficient use of phosphate fertilizers in tropical soils and provide data to soybean producers on the actual efficiency of these fertilizers under real field conditions. I would like to thank the University Center of Patos de Minas (UNIPAM) for supporting and promoting this study. In addition, I thank all colleagues and friends at UNIPAM and the CeFert laboratory for their help throughout the conduct of the study.

\section{References}

Bar-Yosef, B. (1996). Root excretion and their environmental effects: Influence on availability of phosphorus. In Y. Waisel, A. Eshel, \& U. Kafkafi (Eds.), Plant roots: The hidden half. New York.

Benicasa, M. M. P. (2003). Análise do crescimento de plantas (noções básicas) (2nd ed., p. 41). Jaboticabal: FUNEP.

Comissão de Fertilidade do Solo do Estado de Minas Gerais (1999). In A. C. Ribeiro, P. T. G. Guimarães, V. H. V. Alvarez (Eds.), Recomendações para o uso de corretivos e fertilizantes em Minas Gerais (5th Aproximação). Viçosa, MG.

Companhia Nacional de Abastecimento Perspectiva Para a Agropecuária (2020). Safra 2019/2020, Quinto levantamento, Fevereiro. Brasília: CONAB.

Corrêa, J. C., Mauad, M., \& Rosolem, C. A. (2004). Fósforo no solo e desenvolvimento de soja influenciados pela adubação fosfatada e cobertura vegetal. Pesq. Agropec. Bras., 39(12), 1231-1237. https://doi.org/ 10.1590/S0100-204X2004001200010

Dechen, A. R., \& Nachtigall, G. R. (2007). Elementos requeridos à nutrição de plantas. Soil Fertility (1st ed., Cap. 03, pp. 91-132). Viçosa: Sociedade Brasileira de Ciência do Solo.

Dunn, D. J., \& Stevens, A. N. D. G. (2008). Response of rice yields to phosphorus fertilizer rates and polymer coating. Crop Management, 7(1), 1-4. https://doi.org/10.1094/CM-2008-0610-01-RS

EMBRAPA. (2009). In F. C. da Silva (Ed.), Manual de análises quimicas de solos, plantas e fertilizantes (2nd ed.). Brasília, DF: Embrapa Informação Tecnológica.

EMBRAPA. (2017). In P. C. Teixeira, G. K. Donagemma, A. Fontana, W. G. Teixeira (Eds.), Manual de métodos de análise de solo (Editores Técnicos, 3rd ed.). Brasília, DF.

Fink, J. R., Inda, A. V., Torrent, J., \& Barrón, V. (2014). Mineralogy and phosphorus adsorption in soils of south and central-west Brazil under conventional and no-tillage systems. Acta Sci. Agron., 36, 379-87. https://doi.org/10.4025/actasciagron.v36i3.17937

Hopkins, B. G. (2015). Phosphorus in plant nutrition. In D. J. Pilbeam, \& A. V. Barker (Eds.), Plant nutrition handbook (2nd ed., Ch. 3, pp. 65-26). Boca Raton, FL: CRC Press, Taylor \& Francis Group. 
Hopkins, B. G., Fernelius, K. J., Hansen, N. C., \& Eggett, D. L. (2017). AVAIL Phosphorus Fertilizer Enhancer: Meta-Analysis of 503 Field Evaluations. Agronomy Journal, 110(1), 389-398. https://doi.org/10.2134/ agronj2017.07.0385

Köppen, W. (1931). Climatologia. Fundo de Cultura Econômica, México.

Machado, V. J. E., \& Souza, C. H. E. (2012). Disponibilidade de fósforo em solos com diferentes texturas após aplicação de doses crescentes de fosfato monoamônico de liberação lenta. Bioscience Journal, 28, 1-7.

Malavolta, E. (2006). Manual de nutrição mineral de plantas (1st ed.). São Paulo: Editora.

Neto, F., Gravina, G. A., Souza, N. O. S., \& Bezerra, A. A. C. (2010). Adubação fosfatada na cultura da soja na microrregião do Alto Médio Gurguéia. Revista Ciência Agronômica, 41(2), 266-271. https://doi.org/ $10.1590 / \mathrm{S} 1806-66902010000200014$

Novais, R. F., \& Smyth, T. J. (1999). Fósforo em solo e planta em condições tropicais (p. 399). Viçosa, MG, Universidade Federal de Viçosa.

Prochnow, L. I., Chien, S. H., Taylor, R. W., Carmona, G., Henao, J., \& Dillard, E. F. (2003). Characterization and agronomic evaluation of single superphosphates varying in iron phosphate impurities. Agronomy Journal, 95, 293-302. https://doi.org/10.2134/agronj2003.2930

Raghotama, K. O., \& Karthikeyan, A. S. (2005). Phosphate acquisition. Plant Soil, 274, 37-49. https://doi.org/ 10.1007/s11104-004-2005-6

Santos, A. C. M., Carneiro, J. S. S., Leite, R. C., Souza, M. A. S., Freitas, G. A., \& Silva, R. R. (2015). Adubação fosfatada com fertilizante Basiduo ${ }^{\circledR}$ na cultura da soja no oeste da Bahia. Journal of Bioenergy and Food Science, 2(3), 82-90. https://doi.org/10.18607/jbfs.v2i3.25

Sas, L., Rengel, Z., \& Tang, C. (2001). Excess cation uptake and extrusion of próton and organic acid anions in Lupinus albus under P deficiency. Plant Science, 160(6), 1191-1198. https://doi.org/10.1016/S0168-9452 (01)00373-9

Souza, C. H. E. de, Reis, Jr. R. dos, Ribeiro, V. G. S., Machado, M. M., Martins Neto, M., \& Soares, P. H. (2020). Enhanced-Efficiency Phosphorous Fertilizer Impacts on Corn and Common Bean Crops and Soil Phosphorus Diffusion. Journal of Agricultural Science, 12(7), 15. https://doi.org/10.5539/jas.v12n7p15

Sposito, G. (1989). The chemistry of soil. New York: Oxford University Press.

Stauffer, E. (2016). Fertilizante de eficiência aumentada: Adsorção e fluxo difusivo de fósforo. Universidade Federal do Espírito Santo, Brazil.

Stevenson, F. J. (1986). Cycles of: Carbon, nitrogen, phosphorus, sulphur, micronutrients. New York: John Wiley.

Teodoro, P. E., Ribeiro, L. P., Oliveira, E. P. de, Corrêa, C. C. G., \& Torres, F. E. (2015). Path analysis in soybean genotypes as function of growth habit. Bioscience Journal, Uberlândia, 31(1), 161-170. https://doi.org/ 10.14393/BJ-v31n1a2015-22283-

Whalen, J. K., \& Chang, C. (2002). Phosphorus sorption capacities of calcareous soils receiving cattle manure applications for 25 years. Communications in Soil Science and Plant Analysis, 33, 1011-1026. https://doi.org/10.1081/CSS-120003870

Zambolim, L. (2001). Tecnologias de produção de café com qualidade (1st ed.). Viçosa: UFV.

Zanão, L. A., Arf, O., Reis Jr, R. A., \& Pereira, N. (2020). Phosphorus fertilization with enhanced efficiency insoybean and corn crops. Australian Journal of Crop Science, 14, 78-84. https://doi.org/10.21475/ ajcs.20.14.01.p1862

\section{Copyrights}

Copyright for this article is retained by the author(s), with first publication rights granted to the journal.

This is an open-access article distributed under the terms and conditions of the Creative Commons Attribution license (http://creativecommons.org/licenses/by/4.0/). 